\title{
Analysis of factors affecting profitability of sharia commercial banks: evidence from Indonesia
}

\author{
Adhi Widyakto ${ }^{1}$ and Sugeng Wahyudi² \\ ${ }^{1}$ Doctoral Program in Economics, Faculty of Economics and Business, Universitas Diponegoro, Indonesia \\ ${ }^{2}$ Department of Management, Faculty of Economics and Business, Universitas Diponegoro, Indonesia
}

\begin{tabular}{ll}
\hline Abstract & The purpose of this research is to find out the consequences of CAR, LDR, NIM, and FDR \\
on the Profitability of Islamic Commercial Banks in Indonesia in the $2015-2019$ period. \\
Profitability is proxied by ROA as a measure of the amount of profit generated. The sample \\
used in this study is Islamic commercial bank in Indonesia, which has quarterly reports in \\
the $2015-2016$ period. The number of samples used is 18 banks which are taken by \\
purposive sampling method. The analytical method of this study uses multiple linear \\
regression with the SPSS 25 program which previously had passed the classical \\
assumption test. The results of this research show that CAR has a good and significant \\
impact on ROA. LDR has a bad and significant impact on ROA. NIM has a good and \\
significant impact on ROA. FDR has a good and significant impact on ROA.
\end{tabular}

Keywords ROA; CAR; LDR; NIM; FDR

\section{INTRODUCTION}

Bank in Indonesia is a financial intermediary institution that has an important role in the country's economy, whose task is to channel funds to parties in need and from parties who have excess funds and are carried out at a predetermined time (Dendawijaya, 2009: 14). In a broader sense, banking has an important role to maintain the country's economic stability. This can be seen when in the economic sector there is a declining phase and experiencing instability, what is done to restore economic stability is to organize the banking sector (Ubaidillah, 2016). In addition to maintaining stability, the banking sector in Indonesia also plays a role in helping the country's economic progress.

In the banking world, there are two types of banks, namely conventional banking and Islamic banking. The difference between conventional and Islamic commercial banks is that Islamic banks have a prohibition on the practice of interest as is the interest system used in conventional banks (Hamid et al. 2018). At present, Islamic finance is a component that is getting recognition and attention in the international financial system. Because initially Islamic banking arose from the need for Muslims to carry out financial transactions that required the transaction to contain no interest, which clearly in the Qur'an forbids the form of transactions that contain elements of usury. This is supported by the existence of the International Association of Islamic Banks (IAIB) which defines Islamic banking as the implementation of a new concept in world financial practice which fully complies with sharia rules in accordance with Islamic teachings. Therefore, there is a very clear point regarding the clear difference between conventional and Islamic banking regarding the mission and goals and duties to society (Ramlan \& Adnan, 2016).

Regarding the differences between conventional banks and Islamic banks in Indonesia, it is explained in Article 5 of Law No. 10 of 1998, regarding banking, there are 2 types of banks, namely Commercial Banks and Rural Banks. The two types of banks in running their business are classified into two, namely conventional banks and banks with sharia principles. And for the development of Islamic banking running in Indonesia, there has been a drastic increase, this is due to the large demand for Islamic products from the Indonesian population, who are mostly Muslims (Ubaidillah, 2016).

According to Financial Services Authority (OJK) on December 2019, the growth of Islamic banking in Indonesia has increased significantly after the crisis. When this happened, the monetary crisis that occurred in mid-2015 had an impact on the structure of the economy, especially the banking and 
financial structure, which led to a crisis of confidence in the national banking system by the Indonesian people. Islamic banking market shares in Indonesia have continued to grow at the level of $37.39 \%$ since 2015 , from 304 trillion rupiah to 499.34 trillion rupiah in June 2019. Developments continued to increase until 2019, one of which was influenced by Bank Indonesia Regulation.

ROA (Return on Assets) can measure the good or bad performance of a bank caused by several factors. This paper examines the effect of several factors as the determinant of Islamic bank's ROA. The factors that we proposed are the ability owned by banks to maintain capital adequacy as proxied by CAR (Capital Adequacy Ratio), a capability possessed by banks in terms of managing interest rates proxied by NIM (Net Interest Margin), a the ability possessed by the bank in terms of maintaining the level of liquidity proxied by LDR (Loan to Deposit Ratio), and a capability possessed by the bank in terms of reducing the presence of non-performing loans proxied by NPL (Non-Performing Loan).

\section{LITERATURE REVIEW AND HYPOTHESES DEVELOPMENT}

\section{Theory tradeoff between liquidity and profitability}

In practice, profitability and liquidity are simple terms in practice, and now they have become the most important issues for organizations (Nishanthini \& Meerajancy, 2015). Not only commercial banks, profitability and liquidity are important indicators for all profit-oriented businesses because they have an effective role in the health and performance of the company.(Eljelly, 2007). The indicators in question are very important for shareholders and bank depositors.

Banks need to maintain a liquidity position by increasing bank reserves in the company's treasury by using assets owned by banks, causing some assets to be idle, and can reduce profitability for banks, which is said to be based on the theory of tradeoff between liquidity and profitability (Artesa, 2006). The opposite happens if a bank wants to maintain its profitability, it must sacrifice its liquidity. Because cash reserves are sourced from bank assets which are used to meet liquidity needs carried out by banks for investment purposes to generate profitability.

\section{Factors affecting bank's financial performance}

Islamic banking profitability measures the average of total assets compared to the level of management's ability to earn profits. Return on Assets (ROA) according to Bank Indonesia is profit before tax divided by the average total assets and can represent the determination of the level of profitability of banks (Dendawijaya, 2009). Return on Assets $(\mathrm{ROA})$ is more indicative of the ability of banking managers to generate profits obtained through asset management (Yuliani, 2007). According to Karya and Rakhman, the profitability of banking in Indonesia is the best measured by the level of the ratio of profits to assets, both those used for the category of Sharia Business Units and those in the full edge category.

Return on Assets (ROA) is a measure of company performance including sharia banking, but there are several other factors to affect the performance of sharia banking, such as Capital Adequacy Ratio (CAR), Operating Expenses to Operating Income (BOPO), Non Performing Financing (NFP). and Financing to Deposit Ratio (FDR). These variables are able to affect the profitability of Islamic banking (Wibowo \& Syaichu, 2013).

\section{Capital adequacy ratio (CAR)}

Capital is an important aspect for the life of a business unit, including Islamic banking. The assessment of the capital aspect in question is regarding the adequacy of banking capital to anticipate current and future risks. The level of capital ratio which includes the high and low ratio can protect depositors, and is able to give confidence to the public, which in turn is able to have an effect on increasing Return On Assets (ROA). The formation increases the role of assets as a provider of benefits which will later be shown to third parties as suppliers of banking capital. Thus, banks must provide a minimum of capital to ensure the interests of third parties (Sinaungan, 2000).

Measuring the capital adequacy owned by Islamic banking can use the Capital Adequacy Ratio, based on the provisions regulated by the Bank for International 
Settlements, a bank that can be said to be a healthy bank must have a Capital Adequacy Ratio (CAR) value of at least $8 \%$ of capital to risky assets (Muhammad, 2005). Therefore, banks must be able to increase the value of CAR itself, because the greater the value of CAR is able to provide opportunities for banks to generate profits because with large capital, banks can freely place their funds for investment for company profits (Wibowo \& Syaichu, 2013).

\section{Loan to deposit ratio (LDR)}

Loan to Deposit Ratio is a ratio that compares the amount of funds distributed to the community with the amount of funds originating from the community. Loan to Deposit Ratio can be used as a ratio that reflects the liquidity of a bank. The Loan to Deposit Ratio can provide an overview of how deposits, be it time deposits, savings, current accounts, and so on, are used to fulfill loan requests from the bank's customers. Liquidity management can be interpreted as a fairly complicated problem, because the funds managed by banks are almost entirely funds from the public which are short term and can be taken at any time, so it can be concluded that the liquidity of a bank indicates that the bank has sufficient available sources of funds. to be able to meet all of the bank's obligations(Siamat, 2001).

By counting Loan to Deposit Ratio, the bank will know the condition of the bank in running its business, whether in a healthy condition or otherwise. It can be said that the LDR is a ratio used to determine the soundness of a bank (Latumaerissa, 2014). Looking at the Circular Letter of $\mathrm{BI}$ No. 6/23/DPNP As of May 31, 2004, the level of good liquidity is in the range of $50 \%-100 \%$.

\section{Net interest margin (NIM)}

What is meant by Net Interest Margin (NIM) is a measurement ratio that aims to determine the level of profitability (earnings). NIM is basically a financial ratio obtained from the comparison between interest income on assets and also the difference between deposit interest and loan interest (Riyadi, 2006). So it can be concluded that the NIM is basically a financial ratio obtained from the comparison between interest income on assets and also the difference between deposit interest and loan interest.
In other words, NIM is a ratio that shows how a bank's management manages its productive assets in generating net interest income. The larger the NIM ratio indicates that the greater the interest income on productive assets so that the profits obtained by the bank will be even greater. The increase in NIM reflects that the bank is able to increase net interest income (Taswan, 2010).

The factors that can affect the movement of interest rates that will cause changes in Net Interest Margin namely in the form of the need for funds, competition, policies set by the government, expected profit targets, time period, quality of guarantees, reputation owned by the company, competitive products and third party guarantees. (Cashmir, 2013).

\section{Financing to deposit ratio (FDR)}

Financing to Deposit Ratio (FDR) is how much funds from third parties are used for financing (Muhammad, 2005: 265). The third party funds referred to in Islamic banks are (Muhammad, 2005: 266):

Wadiah which is a deposit that guarantees security and returns without obtaining profit or compensation. General investment that is risky from shareholder's profit. Special investment from the bank as an investment manager to earn fees and the full risk of the investment is borne by the investor.

The calculation of the Financing to Deposit Ratio (FDR) is an anticipation of idle funds, these idle funds can occur if there is no balance between pooled funds and disbursed funds. Therefore, banks must be able to use these funds in the form of investments to earn a profit to pay the costs of these funds and other operational costs (Siamat, 1993). According to (Stiawan \& Kodratillah, 2017), FDR is a bank's ability to repay withdrawals made by depositors by controlling liquidity sources for financing.

\section{Effect of capital adequacy ratio (CAR) on return on assets (ROA)}

CAR is the ratio of the capital adequacy owned by a bank when the bank is feared to suffer losses or it can also be said that the capital adequacy ratio that bears assets contains risks. (Dendawijaya, 2001). This ratio helps banks in preparing themselves to anticipate a decline in assets that often 
occurs due to risky assets. According to Bank Indonesia regulations, a bank can be said to be healthy if it has a CAR value of more than $8 \%$, so that by knowing the level of the ratio, the bank will be better prepared to bear any bad events that could happen. A large ratio will reflect that the bank is ready to cope with losses, so to expand the bank will feel safe and is expected to increase profits which will affect the value of Return on Assets (ROA).

Theory of Bank Capital (Diamond \& Rajan, 2000)states that the better the capital owned by the bank, the better the bank's ability to face risks from any credit or other risky productive assets. So that banks will be able to increase the amount of lending and will benefit, because they have sufficient capital to face the possible risks that they will face in the future.

In research conducted by Petria et al. (2015), Naceur (2003), Dietrich \& Wanzenried (2014), Menicucci \& Paolucci (2016) shows that CAR has a positive effect on ROA, with these results it can be formulated that the first hypothesis:

\section{H1: CAR has a positive effect on ROA}

\section{Effect of loan to deposit ratio (LDR) on return on assets (ROA)}

Simorangkir (2004) explained that loan interest is one of the elements of bank income that can increase profitability, the LDR ratio can show how much is the level of allocation of funds obtained from third party funds. According to the Theory of Financial Intermediation of Banking (Werner, 2016), the bank performs its function as an intermediary by channeling funds from surplus units to deficit units, one of which is in the form of credit. A higher LDR ratio can indicate good profitability because successful credit distribution will be able to increase bank profitability.

Research conducted by Prasajaya \& Ramantha (2013), Menicucci \& Paolucci (2016) and Alper \& Anbar (2011) shows that LDR has a positive effect on ROA, with these results it can be formulated that the third hypothesis:

H2: LDR has a positive effect on ROA

\section{Effect of net interest margin (NIM) on return on assets (ROA)}

This ratio compares the net interest income with the total earning assets. This ratio is used to measure the bank's ability in how the bank can manage its productive assets to generate net interest income. Net interest income is calculated by the difference between interest income and interest expense. Earning assets in question can be in the form of credit, securities, and bonds. Thus, every increase in net interest income, will increase the increase in profit before tax, so that the bank's profitability will be able to increase. So, in this case, it shows that there is a relationship between NIM and Profitability where the higher the NIM, the higher the profitability (ROA).

According to Yudha, Chabachib, \& Pangestuti (2017) The biggest source of bank profits comes from lending activities. Therefore, banks are required to utilize productive assets which are then channeled in the form of credit to obtain interest profits. Net interest profit is the difference in interest earned from bank interest. If the bank's interest income is higher than the interest expense, the bank's profitability will increase.

Research conducted by Eng (2013), Krisnawati \& Chabachib (2014), Arimi \& Mahfud (2012), Laryea et al. (2016), and Yudha, Chabachib, \& Pangestuti (2017) shows that NIM has a positive effect on ROA, with these results it can be formulated that the second hypothesis:

\section{H3: NIM has a positive effect on ROA}

\section{Effect of financing to deposit ratio (FDR) on return on assets (ROA)}

The total value of funds from third parties released for Islamic banking financing is called the Financing ro Deposit Ratio (FDR). The higher the value of the FDR ratio indicates that the higher the value of the ratio, the lower the value of banking liquidity, because the amount of funds for financing is getting bigger (Lukman Dendawijaya, 2009: 116). The higher the FDR value, the higher the profitability value, it is assumed that banks are able to channel their funding effectively to increase profits (Yunita, 2014).

Theory Trade off between Liquidity and Profitability say Banks need to maintain their liquidity position by increasing bank reserves 
Table 1.

Sample selection criteria

\begin{tabular}{lc}
\hline \multicolumn{1}{c}{ Criteria } & Amount \\
\hline $\begin{array}{l}\text { Islamic banks which are Sharia } \\
\text { Commercial Banks (BUS) in } \\
\text { the 2015-2019 period }\end{array}$ & 14 \\
Islamic Commercial Banks that \\
issue quarterly financial reports \\
for the period 2015 - 2019 \\
$\begin{array}{l}\text { Samples of Islamic Commercial } \\
\text { Banks that meet the research } \\
\text { criteria }\end{array}$ \\
\hline \multicolumn{2}{c}{ Criteria } \\
\hline $\begin{array}{l}\text { Availability of data to conduct } \\
\text { research in 2015Q1 - 2019Q4 }\end{array}$ \\
$\begin{array}{l}\text { Data not exposed to outliers in } \\
\text { 2015Q1 - 2019Q4 }\end{array}$ \\
$\begin{array}{l}\text { Note. From Bank Indonesia and OJK } \\
\text { (Otoritas Jasa Keuangan). }\end{array}$
\end{tabular}

in the company's treasury by using assets owned by banks, causing some assets to be idle, and can reduce profitability for banks, the opposite happens if banks want to maintain their profitability, they have to sacrifice liquidity. Because cash reserves are sourced from bank assets which are used to meet liquidity needs carried out by banks for investment purposes to generate profitability (Artthesa, 2006).

Based on previous research, such as research conducted by Sriyana (2015), Sabir et al. (2012), Siregar (2018), Ubaidillah (2016), Yunita (2017) and Setiawan \& Kordatilah (2017) who found that. Financing to Deposit Ratio (FDR) has a positive effect on Return on Assets (ROA), so with these results the fourth hypothesis can be formulated:

\section{METHOD}

\section{Population and sample}

The population in this study were Islamic banks registered with Bank Indonesia in $2015-2019$. The sample taken in this study was using purposive sampling which was conducted by selecting samples with previously known population characteristics (Wibowo \& Syaichu, 2013), as for the selection criteria samples were carried out as shown in Table 1.

\section{Measurement}

This study uses eight variables, namely there are four independent variables, CAR (Capital Adequacy Ratio), LDR (Loan to Deposit Ratio), NIM (Net Interest Margin) and Financing to Deposit Ratio (FDR), and one dependent variable, namely ROA (Return on Asset). ROA is used to measure the ability of a company in an effort to gain profits using the assets owned by the company. In the Circular Letter of Bank Indonesia No. 13/30/DPNP On December 16,2011 , the calculation of Return on Assets $(R O A)$ is calculated by the formula:

$$
\mathrm{ROA}=\frac{\text { Profit Before Tax }}{\text { total asset }} \times 100 \%
$$

Capital Adequacy Ratio compares Capital and Risk Weighted Assets (RWA), the minimum size of which is determined by the OJK as a reflection of the health of a

H4: FDR has a positive effect on ROA

Table 2.

Descriptive statistics

\begin{tabular}{lccccc}
\hline & N & Minimum & Maximum & Mean & Std. Deviation \\
\hline CAR (\%) & 135 & 11.54 & 42.30 & 17.6772 & 5.67564 \\
LDR (\%) & 135 & 74.44 & 103.60 & 84.1246 & 5.06445 \\
NIM (\%) & 135 & .56 & 21.39 & 3.4012 & 4.42544 \\
FDR (\%) & 135 & 56.89 & 109.23 & 67.8780 & 6.89337 \\
ROA (\%) & 135 & -.65 & 2.54 & .5613 & .54700 \\
Valid N (listwise) & 135 & & & & \\
\hline
\end{tabular}


Table 3.

F statistical test results

\begin{tabular}{llrrrrr}
\hline & Model & Sum of Squares & df & Mean Square & \multicolumn{1}{c}{ F } & Sig. \\
\hline 1 & Regression & 25.332 & 5 & 5.721 & 671.885 & $.002 b$ \\
& Residual & 1,487 & 134 & .022 & & \\
& Total & 26.060 & 138 & & & \\
\hline
\end{tabular}

a. Dependent Variable: ROA (Y)

b. Predictors: (Constant), CAR (H1), LDR (H2), NIM (H3), FDR (H4)

Note. SPSS $25 \mathrm{Sp}$ data processing results

bank in order to maintain public trust in the bank. CAR is important in the company's development efforts and overcoming the risk of loss. In addition, this ratio can show the ability of the bank in the field of capital to overcome losses in activities carried out by the bank, such as credit and securities trading. According to the Circular Letter of Bank Indonesia No. 13/30/DPNP On December 16, 2011, CAR can be calculated by the following formula:

$$
\mathrm{CAR}=\frac{\text { Capital }}{\text { ATMR }} \times 100 \%
$$

Loan to Deposit Ratio (LDR) is ratio of the total amount of credit and third party funds owned by the bank. This ratio can show the level of bank liquidity. According to the Circular Letter of Bank Indonesia No. 13/30/DPNP On December 16, 2011, LDR can be calculated by the following formula:

$$
\mathrm{LDR}=\frac{\text { amount of credit granted }}{\text { Total } \text { Third Party Funds }} \times 100 \%
$$

Net Interest Margin (NIM) is the ratio of the net interest income with the total earning assets. This ratio is used to measure the bank's ability in how the bank can manage its productive assets to generate net interest income. Net interest income is calculated by the difference between interest income and interest expense. Earning assets in question can be in the form of credit, securities, and bonds. According to the Circular Letter of Bank Indonesia No. 13/30/DPNP On December 16, 2011, NIM can be calculated by the following formula:

$$
\mathrm{NIM}=\frac{\text { Net interest income }}{\text { Average Earning Assets }} \times 100 \%
$$

Financing to Deposit Ratio (FDR) is an indicator used in Islamic banking to show liquidity. This ratio shows the comparison between the total financing disbursed with the total third funding collected (Ubaidillah, 2016). Hence, it can be concluded that the FDR formula is as follows:

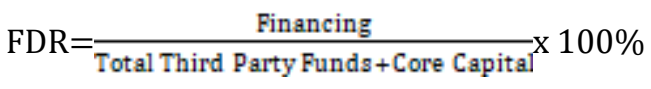

\section{RESULTS}

\section{Descriptive statistics}

According to Ghozali (2018) descriptive statistics provide an overview of the data being studied. While in this study using the variables ROA, CAR, LDR, NIM, and FDR, with the validation of the descriptive statistics above, the data can be obtained in Table 2.

Return on Assets (ROA) which describes the company's ability to earn profits using all of its assets. From the table above can be obtained, the minimum value of ROA -0.65 $(-0.65 \%)$ contained in PT. Bank Mega Syariah in 2015 the second quarter, while the maximum value of $2.54(2.54 \%)$ owned by PT. Bank BNI Syariah in the second quarter of 2016 for the average (mean) of ROA of 0.5613 or $0.5613 \%$ with a standard deviation of $0.54700(0.54700 \%)$.

Capital Adequacy Ratio (CAR) is a calculation comparing core capital and supplementary capital as own capital compared to risk-weighted assets. Based on the table above, it can be obtained, the minimum CAR value of 11.54 (11.54\%) contained in PT. Bank Muamalat Indonesia in the first quarter, for a maximum value of $42.30(42.30 \%)$ at PT. Bank BCA Syariah in the third quarter of 2015 , while the average CAR value was 17.6772 (17.6772 \%) and $5.67564(5.67564 \%)$ for the standard deviation.

Loan to Deposit Ratio (LDR) This ratio compares the total amount of credit with third party funds owned by the bank. This ratio can show the level of bank liquidity. In the table above the minimum value of 74.44 
Table 4.

Coefficient of determination test results

\begin{tabular}{ccccc}
\hline Model & R & R Square & Adjusted R Square & \multicolumn{2}{c}{$\begin{array}{c}\text { Std. Error of the } \\
\text { Estimate }\end{array}$} \\
\hline 1 & $.881 \mathrm{a}$ & .834 & .841 & .10734 \\
\hline
\end{tabular}

a. Predictors: (Constant), CAR (H1), LDR (H2), NIM (H3), FDR (H4)

Note. SPSS $25 \mathrm{Sp}$ data processing results

(74.44\%) contained in PT. Bank BCA Syariah in the first quarter of 2014, while the maximum LDR value is $103.60(103.60 \%)$ at PT. Bank Mega Syariah in 2015 in the second quarter, while the mean value (average) of LDR was 94,1357 (94,1357\%), and for the standard deviation value was 4,08554 (4.08554\%).

Net Interest Margin (NIM) This ratio compares net interest income with total earning assets. This ratio is used to measure the bank's ability in how the bank can manage its productive assets to generate net interest income. shows that the minimum NIM value is $0.56(0.56 \%)$ at PT. Bank BCA Syariah in the 4th quarter of 2017 , for a maximum value of 21.39 (21.39\%) in 2018 the 3rd quarter of which is located at PT. Bank Jabar Banten Syariah, and the average value is $3.4012(3.4012 \%)$ while the standard deviation is 4.42544 (4.42544\%).

Financing to Deposit Ratio (FDR) this ratio is a calculation used in Islamic banking to show liquidity. This ratio shows the comparison between the total financing disbursed with the total third funding collected. Based on Table, it was found that the minimum FDR value of 56.89 (56.89\%) was found at PT. Bank BRI Syariah in the first quarter of 2018, while the maximum value for the FDR variable was 109.23 $(109.23 \%)$ which was found at PT. Bank Victoria Syariah in 2014 2nd quarter. Meanwhile, the average value and standard deviation were $67.8780(67.8780 \%)$ and 6.89337 (6.89337\%).

\section{Classic assumption test}

Before testing the hypothesis by using multiple regression analysis, it is necessary to test the classical assumptions first. Classical assumption test is a way to find out whether there is a deviation from the classical assumptions of the regression results carried out. There are several ways to do the classical assumption test, the test consists of normality test, multicollinearity test, autocorrelation test and heteroscedasticity test. The results show that the data doesn not have problem with normality, multicollinearity, autocorrelation, and heteroscedasticity.

\section{Hypotheses testing}

\section{F-test}

In conducting the simultaneous significance test or the so-called F-test, it shows whether or not there is an affect between the independent variables on the dependent variable, besides that the $f$ statistic test is used to test the level of the regression model meeting the Goodness of Fit or not. The basis used is the profitability standard (sig F) $<0.05$ which has the result that there is a significant effect between the independent variable and the dependent variable. Table 3 shows the results of the $F$ statistical test.

Based on the F- test in the table, it can be seen that the calculated $F$ value is 0.002 . If it is associated with the significance requirements for the $F$ test, it can be obtained that the independent variable has a significant effect on the independent variable. This is because the conditions specified for the $F$ test value on must be below 0.05 which indicates a significant relationship between variables. Thus, it can be concluded that CAR, LDR, NIM, FDR simultaneously significantly affect ROA.

\section{Coefficient of determination test (R2)}

The coefficient of determination (R2) test was conducted to determine the ability of the independent variable to affect the value of the dependent variable. The value shown by R2 has an interval between 0 to 1 , the greater the value of $\mathrm{R} 2$, the greater the ability of the independent variable to affectthe dependent variable. In the data 
Table 5.

t- test

\begin{tabular}{|c|c|c|c|c|c|c|}
\hline \multirow{2}{*}{\multicolumn{2}{|c|}{ Model }} & \multicolumn{2}{|c|}{ Unstandardized Coefficients } & \multirow{2}{*}{$\begin{array}{c}\text { Standardized } \\
\text { Coefficients } \\
\text { Beta }\end{array}$} & \multirow[b]{2}{*}{$\mathbf{t}$} & \multirow[b]{2}{*}{ Sig. } \\
\hline & & B & Std. Error & & & \\
\hline 1 & (Constant) & 11.266 & .129 & & 34.775 & .002 \\
\hline & CAR $(\mathrm{H} 1)$ & .003 & .004 & .043 & 2.477 & .022 \\
\hline & $\operatorname{LDR}(\mathrm{H} 2)$ & -104 & .005 & -1.004 & -34.220 & .002 \\
\hline & $\mathrm{NIM}(\mathrm{H} 3)$ & .008 & .004 & .044 & 3.332 & .016 \\
\hline & FDR $(\mathrm{H} 4)$ & .007 & .002 & .076 & 3.344 & .003 \\
\hline
\end{tabular}

a. Dependent Variable: ROA (Y)

processing carried out, the coefficient of determination test (R2) can be produced as follows in the Table 4.

The results of testing the coefficient of determination in Table 4 can be concluded that the value of Adjusted $\mathrm{R} 2$ in the regression model is 0.941 or $94.1 \%$. This means that the independent variable can explain $94.1 \%$ of the dependent variable (ROA), while $5.9 \%$ is explained by variables that are outside the research model.

\section{t-test}

The t-test aims to see the level of significance regarding the affect between independent variables in influencing the dependent variable. In this study using a significance level of 0.05 or $5 \%$, this indicates that if the significance value is below 0.05 , the independent variable has a significant effect on the dependent variable. Table 5 shows the correlation between CAR, LDR, NIM, and FDR that affect ROA.

The results show that Capital Adequacy Ratio (CAR) have a significant good influence on Return on Assets (ROA). according to the table above, it shows a significance value of 0.022 (smaller than 0.05 ) with a regression coefficient on Unstandardized Coefficients of 0.003 . It can be concluded that CAR has a positive significant effect on ROA, so the first hypothesis which states that CAR has a positive and significant effect on ROA is accepted.

Loan to Deposit Ratio (LDR) has a negative and significant impact on ROA, it can be concluded through the table which shows the sig level is 0.002 (less than 0.05) with a regression coefficient of -0.104 . so that it can be concluded that the relationship between LDR and ROA is significantly negative, for that the second hypothesis which assumes that LDR significant adverse effect on ROA is accepted.

Net Interest Margin (NIM) has a significant good effect on ROA, this can be shown by a significance value of 0.016 (less than 0.05 ) with a regression coefficient of 0.008 . Based on these results, it can be seen that NIM has a positive and significant effect on ROA, so the third hypothesis which states that NIM has a significant negative relationship is rejected.

Financing to Deposit Ratio (FDR) has a significant negative relationship to ROA, through table it can be shown that the significance value of FDR is 0.003 (less than 0.05 ) on $\mathrm{ROA}$, with a regression coefficient of 0.05 . Based on these results, it can be interpreted that FDR has a positive significant relationship with ROA. So the fourth hypothesis which assumes that FDR has a significant positive relationship is accepted.

\section{CONCLUSION}

This study is entitled, analysis of factors that affect the profitability of Islamic commercial banks for the period 2015Q1 - 2019Q2 which explains the effect of CAR, LDR, NIM and FDR to ROA. This research uses SPSS 25 statistical tool for hypothesis testing with multiple regression analysis method. The sample in this study amounted to 18 conventional commercial banks that had the availability of quarterly financial data reports in the 2015-2016 period. The data used was 135 where the data were not exposed to outliers. The results of simultaneous hypothesis testing ( $F$ test) show that the $F$ value is 671.885 with a significance level of 0.000 . The result of testing the coefficient of determination (R2) is $83,4 \%$.

Capital Adequacy Ratio (CAR) has a significant positive effect on Return on 
Assets (ROA). This shows that the increase in CAR affects the rate of increase in profitability with a variable (ROA). LDR has a significant negative effect on ROA. It was found that the smaller the LDR level, the more efficient the company's level, the more efficient it is, the more it has an impact on increasing profitability (ROA).

NIM has a significant positive effect on ROA. It was found that the results of data processing affected by outliers resulted in a significant positive relationship between NIM and ROA. Financing to Deposit Ratio (FDR) has a significant positive effect on ROA. Each high level of FDR has an effect on increasing profitability (ROA).

Despite some contributions that this study may have, it also has some limitations. First, there are outliers in the study, which causes a reduction in the data used, from a total of 220 data used to 147 data used. So that it has not been able to fully explain the analysis carried out on Conventional Commercial Banks in Indonesia.

Second, the period for the research was relatively short with data collected only 4 years, with quarterly data for the period 2015 to 2019. Third, there are several other factors that can be used such as NOM and inflation used by Sabir et al. (2012), Wibowo \& Syaichu (2013), Said \& Ali (2016) because there are still $5.9 \%$ of factors outside the study that affect profitability.

\section{REFERENCES}

Alper \& Anbar (2011). Bank Speciafic and macroeconomic determinants of Commercial bank profitability Empirical evidence from Turkey. Business and Economics Research Journal.

Siamat, D. (1993). Commercial Bank Management. Intermedia, Jakarta.

Dendawijaya, L. (2009). Banking management. Jakarta: Ghalia Indonesia.

Diamond, DW, \& Rajan, RG (2000). American Finance Association A Theory of Bank Capital. The Journal of Finance, 55(6), 2431-2465.

https://doi.org/10.1111/jofi.I2189

Eljelly, AMA (2007). International Journal of Commerce and Management Emerald Article : Liquidity - profitability tradeoff : An empirical investigation in an emerging market.

Ghozali, I. (2018). Applications of Multivariate Analysis With IBM SPSS 25 Program (9th Edition). Semarang: Undip Publishing Agency.

Kodratillah, OI, \& Setiawan, DC (2017). No TitleExamining Banks Profitability and Banks Efficiency of Islamic Commercial Banks in Indonesia. Asia-Pacific Business Research Conference.

Lestari, R.I., Indarto, I. (2021). The Relationship between Debt Securities Issuance and Operational Performance: An Empirical Study of Banks in Indonesia. Journal of Asian Finance, Economics and Business Vol 8 No 6 (2021) 0731-0740

Lestari, R. I., Wahyudi, S., Muharam, H., \& Ariyanto, E. (2020). The effect of profit efficiency toward banks performance: Does bond issuance matter? In Test Engineering and Management. MarchApril 2020 ISSN: 0193-4120 Page No. 5537 - 5549

Sabir, M., Muhammad, A., \& Abd Hamid, H. (2012). The effect of bank health ratios on the financial performance of Islamic commercial banks and conventional banks in Indonesia. Journal of Analysis, 1(1), 79-86.

Menicucci, E. Paolucci, G. \& Paoloni, N. (2019). Does gender matter for hotel performance ? Evidence from the Halian hospitality Industry. International Joaurnal of Tourism Research, 21(5),625-638

Muhammad. (2005). Islamic Bank Management (U. AMPYKPN, ed.). Yogyakarta.

Nishanthini, A., \& Meerajancy. (2015). No TitleTrade-Off between Liquidity and Profitability: A Comparative Study between State Banks and Private Banks in Sri Lanka.

Ramlan, H., \& Adnan, MS (2016). The Profitability of Islamic and Conventional Banks: Case Study in Malaysia. Procedia Economics and Finance, 35(October 2015), 359-367. https://doi.org/10.1016/s22125671(16)00044-7

Said, M., \& Ali, H. (2016). An analysis on the factors affecting the profitability level of Sharia banking in Indonesia. Banks and Bank Systems, 11(3), 28-36. https://doi.org/10.21511/bbs.11(3).2016 .03

Sartono, A. (2001). Financial Management.

Setiawan \& Kodratillah. (2017). Examining Banks Probability and Banks Efficiency of Islamic Commercial Bank Indonesia. Asia- Pasific Business Research Conference 
Sinungan, M. (2000) Bank Management Facing the years 2000 and the Banking law 1992. Publication IAIN Batusangkar

Siregar, P. (2018). Analysis of Factors Affecting Profitability of Islamic Banking in Indonesia. HUMAN FALAH, 5, 2.

Soemitra, A. (2009). Islamic Banks and Financial Institutions (P. Media, ed.). Jakarta.

Sriyana, J. (2015). Islamic Banks' Profitability Amid the. International Journal of Applied Business and Economic Research, 13(4), 1695-1710.

Syaichu, M., \& Wibowo, E. (2013). Analysis of The Effect of Interest Rate, Inflation, CAR, NIM, FDR, LDR On Profitability Of Sharia Bank. 2, 1-10. Retrieved from http://ejournal-

s1.undip.ac.id/index.php/djom

Taswan. (2010). The Analysis of Insider Ownership, Debt \& Dividend Policy on Value of Firm and The Affecting Factors, Journal Business and Economic

Ubaidillah. (2016). Analysis of Factors Affecting Profitability of Islamic Banks in Indonesia. Islamic Economics Journal, $4,1$.

Wibowo \& Syaichu (2013). Analysis of effect of interest rates, inflaction, CAR, BOPO,NPF, on the Profitability of Islamic Banks. Diponegoro Journal of Management.

Yunita. (2014). Factors Affecting the Profitability Level of Islamic Banking in Indonesia. Indonesian Journal of Accounting, 3(2), 143-160.

Yusuf, Muhammad (2017). Dampak Indikator Rasio Keuangan terhadap Profitabilitas Bank Umum Syariah di Indonesia. Jurnal Keuangan dan Perbankan, 13(2), 141-151.

http://journal.ibs.ac.id/index.php/jkp/arti cle/view/53 